\title{
EFFECT OF DIFFERENT METHODS OF TREATMENT OF MUNICIPAL SEWAGE SLUDGE ON THEIR PHYSICOCHEMICAL PROPERTIES AND THEIR AGRICULTURAL UTYLIZATION
}

\author{
Elżbieta Malinowska', Kazimierz Jankowski', Beata Wiśniewska-Kadżajan', \\ Jacek Sosnowski' ${ }^{1}$, Roman Kolczarek ${ }^{1}$ \\ 1 Institute of Agronomy, Siedlce University of Natural Sciences and Humanities, Prusa, Siedlce, Poland, e-mail: \\ malinowskae@uph.edu.pl
}

Received: 2015.01.16

Accepted: 2015.02.07

Published: 2015.04.01

\begin{abstract}
In the study the physicochemical properties of selected municipal sewage sludge were compared using the reports on waste generation from the years 2007-2012 in the Mazovia voivodship. The selection was done on the basis of different methods of sludge processing and the number of equivalent inhabitants (NEJ) supported by sewage. Physical and chemical properties of municipal sewage sludge were significantly dependent on the method of purification and treatment methods. These sludges were characterized by a high content of organic matter and macronutrients. The amount of heavy metals $(\mathrm{Pb}, \mathrm{Cd}, \mathrm{Cr}, \mathrm{Cu}, \mathrm{Ni}, \mathrm{Hg}$ and $\mathrm{Zn}$ ) were within acceptable standards for municipal sewage sludge used in agriculture. Municipal sewage sludge treated by biological method with higher nutrients removal did not create bacteriological danger and were used in agriculture, generally to the cultivation of all agricultural products. Sewage sludge sanitized with lime and subjected to anaerobic digestion did not meet bacteriological standards, which eliminated their use in agriculture.
\end{abstract}

Keywords: municipal sewage sludge, physicochemical properties, agricultural utilization.

\section{INTRODUCTION}

The chemical composition of sewage sludge is very varied, dependent on the season of year, the city's infrastructure and the quantity and quality of effluents discharged by the industry to municipal wastewater treatment plants. Processes in sewage directly or indirectly affect the sediment, changing its properties. The processes selection of sludge treatment has a significant influence on the subsequent their utilization [Simonetti et al. 2014]. Most often municipal wastewater in treatment plants are mechanically and biologically treated. In this process significant amounts of soluble organic substances, difficulty sedimenting suspensions and colloids, reducing the amount of viruses and bacteria are removed from the waste water. From the inorganic substances only those absorbed by microorganisms the nitrogen and phosphorus com- pounds are removed. The stream of municipal sewage sludge in Poland are increasing rapidly, as is the effect of dynamically running modernization and the introduction of more advanced wastewater treatment technology or the construction of new wastewater treatment [Stypka, Flaga-Maryańczyk 2013]. The approach to the sludge from the technology site of little or no waste is at the moment one of the most important aspects [Leszczyński, Brzychczyk 2007, Pawłowski et al. 2000]. Municipal sewage sludge, in accordance with the legislation in force in Poland can be used for fertilizer, as evidenced by the operating law regulations, including the Act on Waste [2012] and the Regulation of the Minister of Environmental Protection [2002, 2010]. The suitability of sewage sludge to agricultural utilization is determined bysuch factors as: the content of organic matter, nutrients for plants, content of permanently damaging (undegradable 
and degradable very difficult) to the environment, the presence of pathogenic organisms, consistency [Simonetti et al. 2014].

The aim of the study was to evaluate the physicochemical properties of municipal sewage sludge treated by various methods from selected wastewater treatment plants with different throughput mass of Mazovia voivodship.

\section{MATERIAL AND METHODS}

The paper presents the results of studies from the reports on waste generation in the years 2007 2012 in the Mazovia voivodship [Report of the production of waste]. Of the 598 municipal wastewater and industrial treatment plants exploited in Mazovia - as in 2012 [http://wios. warszawa.pl], four municipal sewage treatment plants using different methods of treatment were selected. On the basis of the wastewater load the treatment plant was expressed by a number of equivalent inhabitants (NEJ) tested treatments were classified to II, III, IV and V group. Group I - treatment support up to 2 thousand of NEJ, II $-2-10$ thousand of NEJ, III - 10-50 thousand of NEJ, IV - 50-100 thousand of NEJ V - over 100 thousand of NEJ. Most of the selected wastewater treatment uses biological method of sludge treatment. Administrative policy of the community and the activities of exploiter can significantly affect the quality of the produced sludge, as well as its quantity. Two of the selected treatment plants belonging to II and III group purified and wastewater by biological method with increased nutrient removal (MB). Wastewater treatment by this method allows an increased reduction of nitrogen and phosphorus. Sludge from wastewater treatment plants belonging to the second group is subjected to further composting (MB-K). This process ensures the stabilization of organic compounds, natural disinfection, reducing the weight of sludge and production of a stable final product. In the largest wastewater treatment plants (group V) in Warsaw sewage sludge is disposed in the anaerobic process (fermentation) (MB-F). In the next wastewater treatment (group IV) chemical method for treatment of waste water is used by the addition of quicklime (MCh-CaO). The estimation of sewage sludge includes such parameters as $\mathrm{pH}$, content of viable eggs of parasites, the dry matter, organic matter content, macronutrients, except for potassium, and the content of heavy metals. Reports show that the sediments produced by the selected treatment in Mazovia province were not always clean in bacteriological terms (Table 1).

Table 1. Number of live eggs of parasites in municipal sewage sludge treated by various methods in Mazovia voivodship in the years 2007-2012

\begin{tabular}{|l|c|c|c|}
\hline \multirow{2}{*}{ Sewage sludge } & \multicolumn{3}{|c|}{ Year } \\
\cline { 2 - 4 } & 2007 & 2009 & 2012 \\
\hline MB-K (G II) & 0 & 0 & 0 \\
\hline MB (G III) & 0 & 0 & 0 \\
\hline MCh-CaO (G IV) & 0 & 198.0 & 0 \\
\hline MB-F (G V) & 0 & 93.0 & 155.0 \\
\hline
\end{tabular}

Data on the content of macronutrients and heavy metals were compared statistically using Statistica program, Version 10.0 StatSoft, for a detailed comparison of the mean values Tuke'y test at $\mathrm{p}<0.05$ were used.

\section{RESULTS AND DISCUSSION}

Physical and chemical properties of municipal sewage sludge are variable, depending primarily on the type of sewage, method of purification and processing methods [Maćkowiak 2000]. The analysis (table 2) shows that the lowest $\mathrm{pH}$ average 6.16 was characterized by sludge from sewage treatment plants applying biological treatment associated with composting, and almost twice higher $\mathrm{pH}$ value $=12$ was recorded in the sludge from wastewater applying lime stabilization. Deacidifying activity of sewage sludge used in agriculture is confirmed by the research of many authors [Speir et al. 2003]. The dry matter content in sewage sludge ranged from 22.63 to $51.5 \%$. The highest content of dry matter was characterized by sludge from a biological treatment plant with increased nutrient removal and the least sludge subjected to fermentation. Municipal sewage sludge contain diverse content of organic matter, which ranged from $16.7 \%$ to $51.7 \%$. Most of organic matter was observed in the sediment subjected to composting. Maćkowiak [2000], based on eight years of research gives an average of $50.62 \%$ of organic matter in municipal sewage sludge and agri-food sewage in Polish. Sanitary characteristics of sewage sludge are variable and are based on many factors, among others, dependent on the quality of life and health status of residents in the area, the type of treated wastewater and process- 
Table 2. Mass and selected parameters of municipal sewage sludge

\begin{tabular}{|c|c|c|c|c|c|c|c|c|c|c|c|c|}
\hline \multirow{3}{*}{ Sewage sludge } & \multicolumn{2}{|c|}{$\begin{array}{c}\text { Mass of sewage } \\
\text { sludge (Mg / years) }\end{array}$} & \multirow{2}{*}{$\begin{array}{c}\text { Aim of } \\
\text { application }\end{array}$} & \multicolumn{3}{|c|}{$\mathrm{pH}$} & \multicolumn{3}{|c|}{ D.M. (\%) } & \multicolumn{3}{|c|}{$\begin{array}{c}\text { Organic material } \\
\text { (\% D.M.) }\end{array}$} \\
\hline & F.M. & D.M. & & $\min$. & max. & average & $\min$. & $\max$. & average & $\min$. & $\max$ & average \\
\hline & \multicolumn{12}{|c|}{2007} \\
\hline MB-K (G II) & 756000 & 227000 & 1 & 5.30 & 6.80 & 5.80 & 21.5 & 32.0 & 26.0 & 41.3 & 57.8 & 51.7 \\
\hline MB (G III) & 1309000 & 261880 & 3 & 8.27 & 8.07 & 7.90 & 49.9 & 64.3 & 51.5 & 13.3 & 17.9 & 16.7 \\
\hline $\begin{array}{l}\text { MCh-CaO } \\
\text { (G IV) }\end{array}$ & 1843000 & 626900 & 5 & 11.2 & 11.7 & 11.4 & 28.2 & 38.9 & 34.0 & 17.0 & 26.5 & 20.5 \\
\hline MB-F (G V) & 1329000 & 342000 & 5 & 8.50 & 12.0 & 11.0 & 16.5 & 33.8 & 22.6 & 38.1 & 65.5 & 53.4 \\
\hline \multicolumn{13}{|c|}{2009} \\
\hline MB-K (G II) & 807000 & 242000 & 1 & 6.10 & 6.50 & 6.30 & 31.8 & 42.3 & 37.1 & 32.0 & 45.3 & 38.7 \\
\hline MB (G III) & 1317000 & 263000 & 1 & 7.47 & 8.46 & 7.86 & 24.8 & 50.7 & 35.2 & 18.1 & 33.5 & 28.0 \\
\hline MCh-CaO (G IV) & 3750000 & 1200000 & 5 & 12.0 & 12.5 & 12.2 & 27.8 & 36.6 & 32.0 & 23.3 & 40.5 & 31.8 \\
\hline MB-F (G V) & 56810700 & 16313000 & 5 & 7.80 & 12.5 & 8.80 & 22.5 & 45.9 & 28.5 & 20.7 & 54.4 & 45.6 \\
\hline \multicolumn{13}{|c|}{2012} \\
\hline MB-K (G II) & 696000 & 209000 & 1 & 5.70 & 6.76 & 6.37 & 35.1 & 37.8 & 36.7 & 43.2 & 45.8 & 44.6 \\
\hline MB (G III) & 1217000 & 245000 & 1 & 7.00 & 8.25 & 7.82 & 15.3 & 32.9 & 21.6 & 29.0 & 64.4 & 44.9 \\
\hline MCh-CaO (G IV) & 3160000 & 742000 & 5 & 12.5 & 12.5 & 12.5 & 18.5 & 28.1 & 23.5 & 36.2 & 50.9 & 43.6 \\
\hline MB-F (G V) & 3731000 & 836750 & 5 & 10.1 & 13.2 & 11.9 & 20.4 & 27.2 & 23.3 & 23.4 & 42.7 & 35.0 \\
\hline \multicolumn{13}{|c|}{ Average of the years } \\
\hline MB-K (G II) & 753000 & 226000 & & 5.70 & 6.69 & 6.16 & 29.5 & 37.4 & 33.3 & 38.8 & 49.6 & 45.0 \\
\hline MB (G III) & 1281000 & 256629 & & 7.58 & 8.26 & 7.86 & 30.0 & 49.3 & 36.1 & 20.1 & 38.6 & 29.9 \\
\hline MCh-CaO (G IV) & 2917000 & 856300 & & 11.9 & 12.2 & 12.0 & 24.8 & 34.5 & 29.8 & 25.5 & 39.3 & 31.9 \\
\hline MB-F (G V) & 20623000 & 5830583 & & 8.80 & 12.6 & 10.6 & 19.8 & 35.6 & 24.8 & 27.4 & 54.2 & 44.7 \\
\hline
\end{tabular}

Table 3. Content of selected macroelements ( $\mathrm{g} \cdot \mathrm{kg}^{-1}$ D.M.) in municipal sewage sludge

\begin{tabular}{|c|c|c|c|c|c|c|c|c|c|c|c|c|}
\hline \multirow{3}{*}{ Sewage sludge } & \multicolumn{3}{|c|}{$N$} & \multicolumn{3}{|c|}{$P$} & \multicolumn{3}{|c|}{$\mathrm{Ca}$} & \multicolumn{3}{|c|}{$\mathrm{Mg}$} \\
\hline & $\min$. & $\max$. & average & $\min$. & $\max$. & average & $\min$. & max. & average & $\min$. & max. & average \\
\hline & \multicolumn{12}{|c|}{2007} \\
\hline MB-K (G II) & 18.4 & 19.0 & 18.7 & 19.0 & 49.5 & 36.2 & 25.2 & 37.3 & 32.7 & 4.61 & 4.50 & 4.60 \\
\hline MB (G III) & 48.0 & 84.0 & 70.0 & 8.50 & 9.70 & 9.10 & 1.20 & 20.5 & 10.1 & 0.60 & 3.60 & 2.30 \\
\hline MCh-CaO (G IV) & 22.0 & 30.0 & 27.0 & 11.0 & 18.0 & 14.0 & 179.0 & 300.0 & 247.0 & 3.00 & 4.30 & 3.80 \\
\hline MB-F (G V) & 26.0 & 51.0 & 39.3 & 21.0 & 37.5 & 29.8 & 45.2 & 100.7 & 76.4 & 5.10 & 8.26 & 6.50 \\
\hline \multicolumn{13}{|c|}{2009} \\
\hline MB-K (G II) & 16.2 & 25.4 & 20.8 & 34.2 & 38.3 & 36.3 & 39.9 & 44.3 & 42.1 & 4.80 & 5.00 & 4.90 \\
\hline MB (G III) & 11.1 & 15.7 & 13.3 & 8.50 & 17.3 & 12.4 & 8.60 & 31.2 & 17.4 & 2.70 & 6.50 & 4.90 \\
\hline MCh-CaO (G IV) & 19.1 & 31.0 & 24.1 & 1.40 & 22.3 & 8.15 & 81.3 & 246.0 & 153.0 & 2.50 & 5.70 & 3.70 \\
\hline MB-F (G V) & 11.3 & 40.0 & 30.3 & 13.2 & 27.2 & 21.8 & 9.80 & 19.0 & 14.6 & 3.30 & 5.30 & 4.20 \\
\hline \multicolumn{13}{|c|}{2012} \\
\hline MB-K (G II) & 20.8 & 23.4 & 22.3 & 28.1 & 37.6 & 33.8 & 33.6 & 41.4 & 37.3 & 3.90 & 4.50 & 4.10 \\
\hline MB (G III) & 30.2 & 42.6 & 36.5 & 25.3 & 51.1 & 41.6 & 38.7 & 59.5 & 46.3 & 6.90 & 24.4 & 16.0 \\
\hline MCh-CaO (G IV) & 26.2 & 49.9 & 34.5 & 13.5 & 21.1 & 18.2 & 155.0 & 263.0 & 209.5 & 3.90 & 5.00 & 4.40 \\
\hline MB-F (G V) & 20.3 & 33.0 & 28.2 & 9.80 & 19.0 & 14.6 & 150.0 & 239.0 & 191.3 & 4.78 & 5.93 & 5.47 \\
\hline \multicolumn{13}{|c|}{ Average of the years } \\
\hline MB-K (G II) & 18.5 & 22.6 & 20.6 & 27.1 & 41.8 & 35.4 & 32.9 & 41.0 & 37.4 & 4.44 & 4.67 & 4.53 \\
\hline MB (G III) & 29.8 & 47.4 & 39.9 & 14.1 & 26.0 & 21.0 & 16.2 & 37.1 & 24.6 & 3.40 & 11.5 & 7.73 \\
\hline MCh-CaO (G IV) & 22.4 & 36.9 & 28.5 & 8.63 & 20.5 & 13.5 & 138.4 & 269.7 & 203.2 & 3.13 & 5.00 & 3.97 \\
\hline MB-F (G V) & 19.2 & 41.3 & 32.6 & 14.7 & 27.9 & 22.1 & 68.3 & 119.6 & 94.1 & 4.39 & 6.50 & 5.39 \\
\hline $\begin{array}{l}\mathrm{LSD}_{0.05} \text { for: } \\
\text { A-methods of sludge } \\
\text { treatment }\end{array}$ & 1.60 & 4.41 & 3.81 & 0.898 & 0.733 & 0.724 & 3.84 & 8.02 & 1.44 & 0.277 & 0.745 & 0.543 \\
\hline B -years & 1.25 & 3.46 & 2.98 & 0.704 & 0.575 & 0.568 & 3.01 & 6.29 & 1.13 & 0.217 & 0.584 & 0.426 \\
\hline A/B- interaction & 2.51 & 7.46 & 6.60 & 1.56 & 1.27 & 1.25 & 6.66 & 13.9 & 2.49 & 0.479 & 1.29 & 0.940 \\
\hline $\mathrm{B} / \mathrm{A}$ - interaction & 2.77 & 6.92 & 5.98 & 1.41 & 1.15 & 1.14 & 6.03 & 12.6 & 2.26 & 0.434 & 1.17 & 0.851 \\
\hline
\end{tabular}


ing methods [Sahlström et al. 2004, Bagge et al. 2005, Walczak, Lalke-Porczyk 2009]. The data show that smaller wastewater treatment plants produce sludge bacteriological safe, which can be used in agriculture, in general, to the cultivation of all agricultural products (Table 1,2).

The content of biogenic elements (essential in plant nutrition) in the presented sewage sludge was significantly varied and depends on the method of wastewater treatment (Table. 3). Sludges are very rich in nitrogen, phosphorus, magnesium. The amounts of these macronutrients are usually much higher than in manure [RosikDulewska 2000, 2001, Skorbiłowicz 2002]. The nitrogen content ranged from 20.6 to $39.9 \mathrm{~g} \mathrm{~kg}^{-1}$, with variations from 11.1 to $84 \mathrm{~g} \mathrm{~kg}^{-1}$. Phosphorus content was on average from 13.5 to $35.4 \mathrm{gkg}^{-1}$, magnesium from 3.97 to $7.73 \mathrm{gkg}^{-1}$. Very large amounts of calcium in the sludge hygenizated with $\mathrm{CaO}$ have been reported. The average content of the element was $203.2 \mathrm{gkg}^{-1}$, and in the remaining sewage sludges it was much lower, up to 5-fold. The contents of macronutrients in these sludges are comparable with the results of many authors [Mazur 2000, Jakubus 2005, 2006, Malinowska, Kalembasa 2013].

In the sludge the main criterion for their eligibility for the natural use is the content of heavy metals [Czechowska-Kosacka 2007]. In these sludge did not exceed the permissible content of heavy metals [Regulation 2010] (Table 4, 5).

The average lead content in sewage sludge ranged in each year on average from 9.80 to 42.8 $\mathrm{mg} \cdot \mathrm{kg}^{-1}$ (Table 4). As follows from the data content of this metal in the sludges stabilized by different methods did not exceed $35 \mathrm{mg} \cdot \mathrm{kg}^{-1}$ D.M. It was reported that sludges analyzed in 2012 contained much less lead than in previous years. Maćkowiak [2000] obtained similar content of lead in municipal sewage sludge in eight years of research. The average cadmium content ranged from $0.420 \mathrm{mg} \mathrm{kg}^{-1}$ in sewage sludge stabilized with lime to $11.7 \mathrm{mg} \mathrm{kg}^{-1}$ in sludges subjected to fermentation, from sewage treatment plant with the largest throughput mass. The chromium content in sewage sludge was significantly varied and

Table 4. Contents of selected heavy metals ( $\mathrm{mg} \cdot \mathrm{kg}^{-1}$ D.M.) in municipal sewage sludge

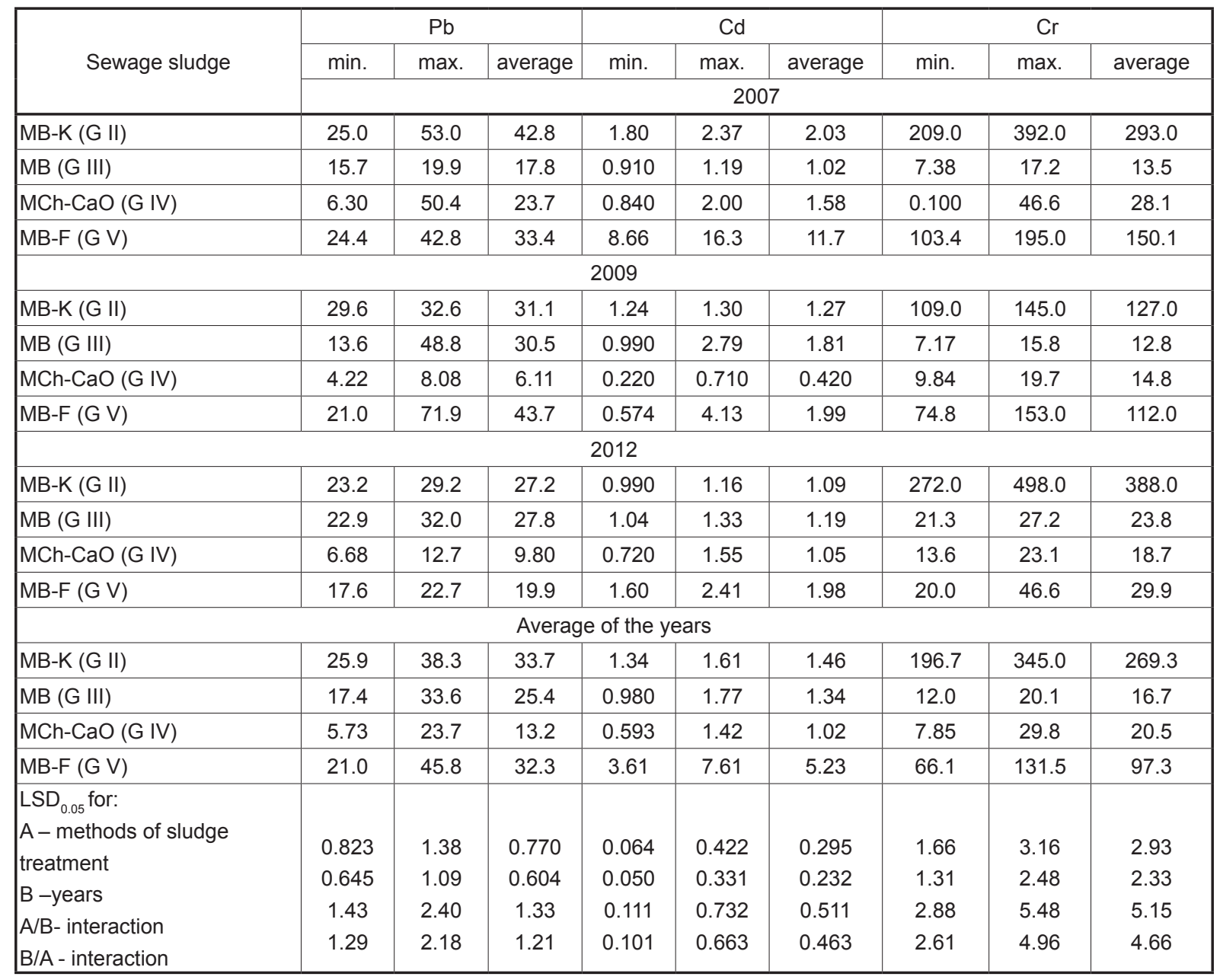


Table 5. Contents of selected heavy metals ( $\mathrm{mg} \cdot \mathrm{kg}^{-1}$ D.M.) in municipal sewage sludge

\begin{tabular}{|c|c|c|c|c|c|c|c|c|c|c|c|c|}
\hline \multirow{3}{*}{ Sewge sludge } & \multicolumn{3}{|c|}{$\mathrm{Cu}$} & \multicolumn{3}{|c|}{$\mathrm{Ni}$} & \multicolumn{3}{|c|}{$\mathrm{Hg}$} & \multicolumn{3}{|c|}{$\mathrm{Zn}$} \\
\hline & $\min$. & max. & average & $\min$. & max. & average & $\min$. & max. & średnia & $\min$. & max. & average \\
\hline & \multicolumn{12}{|c|}{2007} \\
\hline MB-K (G II) & 124.0 & 176.0 & 144.3 & 23.5 & 32.3 & 27.6 & 0.880 & 1.28 & 1.04 & 900.0 & 1026.0 & 956.3 \\
\hline MB (G III) & 53.4 & 67.3 & 59.9 & 7.40 & 62.7 & 26.6 & 0.210 & 0.420 & 0.330 & 395.0 & 493.0 & 444.3 \\
\hline MCh-CaO (G IV) & 79.8 & 233.0 & 148.0 & 1.00 & 17.9 & 10.1 & 0.280 & 0.500 & 0.370 & 485.6 & 985.0 & 785.9 \\
\hline MB-F (G V) & 201.2 & 274.0 & 244.9 & 23.4 & 53.8 & 34.5 & 3.50 & 4.21 & 3.85 & 1619.6 & 2567.0 & 2054.5 \\
\hline \multicolumn{13}{|c|}{2009} \\
\hline MB-K (G II) & 122.0 & 133.0 & 127.5 & 20.4 & 31.6 & 26.0 & 0.630 & 0.730 & 0.680 & 763.0 & 818.0 & 790.5 \\
\hline MB (G III) & 59.9 & 41.0 & 162.0 & 10.1 & 18.6 & 13.0 & 0.400 & 3.66 & 1.50 & 256.0 & 852.0 & 606.7 \\
\hline MCh-CaO (G IV) & 11.3 & 79.3 & 49.7 & 8.57 & 14.8 & 11.9 & 0.130 & 0.190 & 0.150 & 335.0 & 381.0 & 359.0 \\
\hline MB-F (G V) & 141.0 & 361.0 & 256.0 & 37.1 & 91.8 & 66.5 & 0.170 & 1.74 & 0.780 & 521.0 & 1212.0 & 973.0 \\
\hline \multicolumn{13}{|c|}{2012} \\
\hline MB-K (G II) & 112.0 & 128.0 & 121.0 & 28.0 & 33.5 & 30.0 & 0.360 & 0.660 & 0.520 & 652.0 & 877.0 & 777.3 \\
\hline MB (G III) & 159.0 & 270.0 & 222.3 & 14.2 & 16.5 & 15.6 & 0.140 & 0.660 & 0.450 & 823.0 & 1092.0 & 956.7 \\
\hline $\mathrm{MCh}-\mathrm{CaO}$ (G IV) & 97.3 & 258.0 & 155.3 & 5.39 & 10.6 & 8.80 & 0.160 & 1.51 & 0.540 & 589.0 & 819.0 & 658.0 \\
\hline MB-F (G V) & 89.1 & 134.0 & 113.7 & 10.5 & 13.3 & 11.7 & 0.690 & 1.06 & 0.890 & 569.0 & 1070.0 & 783.0 \\
\hline \multicolumn{13}{|c|}{ Average of the years } \\
\hline MB-K (G II) & 119.3 & 145.7 & 130.9 & 23.9 & 32.5 & 27.9 & 0.623 & 0.890 & 0.746 & 771.7 & 907.0 & 841.4 \\
\hline MB (G III) & 90.8 & 126.1 & 148.1 & 10.6 & 32.6 & 18.4 & 0.250 & 1.58 & 0.760 & 491.3 & 812.3 & 669.2 \\
\hline $\mathrm{MCh}-\mathrm{CaO}$ (G IV) & 62.8 & 190.1 & 117.7 & 4.99 & 14.4 & 10.3 & 0.190 & 0.733 & 0.353 & 469.9 & 728.3 & 601.0 \\
\hline MB-F (G V) & 143.8 & 256.3 & 204.9 & 23.7 & 52.9 & 37.6 & 1.45 & 2.34 & 1.84 & 903.2 & 1616.3 & 1270.2 \\
\hline $\begin{array}{l}\mathrm{LSD}_{0.05} \text { for: } \\
\text { A - methods of } \\
\text { sludge treatment }\end{array}$ & 1.87 & 5.88 & 1.12 & 0.542 & 6.77 & 0.959 & 0.205 & 0.061 & 0.071 & 37.7 & 32.0 & 29.6 \\
\hline B -years & 1.47 & 4.61 & 0.879 & 0.425 & 5.31 & 0.752 & 0.161 & 0.052 & 0.059 & 29.6 & 28.3 & 25.4 \\
\hline$A / B$ - interaction & 3.24 & 10.2 & 1.94 & 0.938 & 11.7 & 1.66 & 0.355 & 0.104 & 0.121 & 65.3 & 56.2 & 51.3 \\
\hline $\mathrm{B} / \mathrm{A}$-interaction & 2.93 & 9.22 & 1.76 & 0.849 & 10.6 & 1.50 & 0.321 & 0.093 & 0.109 & 59.2 & 48.3 & 45.2 \\
\hline
\end{tabular}

ranged on average from 12.8 to $388 \mathrm{mg} \cdot \mathrm{kg}^{-1}$. The highest content of this element was observed in the biologically stabilized sludges and subjected to a process of composting.

The content of other heavy metals (copper, nickel, mercury and zinc) in the sludge was significantly dependent on the processing method (Table 5).

The copper content was on average from 49.7 to $244.9 \mathrm{mg} \cdot \mathrm{kg}^{-1}$ and was highest in sludge from wastewater plants applying fermentation, with the exception of 2012. A similar correlation was observed for the other heavy metals. The nickel content ranged from 8.80 to $66.5 \mathrm{mg} \mathrm{kg}^{-1}$. The average content from six years did not exceed 40 $\mathrm{mg} \mathrm{Ni} \cdot \mathrm{kg}^{-1}$ D.M. of sludge and was more than 8-fold lower than that allowed for municipal sewage sludge for use in agriculture. Mercury is a highly toxic element which forms common environmental pollution [Gochefeld 2003, Wang et al. 2004]. It was observed decrease in the content of this metal in these sludge in the period considered. The average mercury content ranged from 0.330 to $1.50 \mathrm{mg} \cdot \mathrm{kg}^{-1}$ and $\mathrm{Hg}$ standard for sludge is 16 $\mathrm{mg} \cdot \mathrm{kg}^{-1}$. Toxicity of zinc is much lower than of mercury, cadmium or lead, the metal presents the highest toxic risk for biomass in the soil. The high content of this element in the sludge used in agriculture may pose a threat to soil microorganisms. The zinc content in these sewage sludges ranged from 359.0 to $2054 \mathrm{mg} \cdot \mathrm{kg}^{-1}$, the average from six years did not exceed $1300 \mathrm{mg} \cdot \mathrm{kg}^{-1}$. According to Wardas et al. [2002] the source of this metal in municipal sewage sludge can be galvanized water pipes, as well as large amounts of chlorine regulating the bacteriological state of water.

Based on the evaluated parameters was found that municipal sewage sludge produced by different methods in the Mazovia voivodship in the years 2007-2012 in terms of chemical composition are valuable waste, which can be used in agriculture for the cultivation of all agricultural products. Sanitary standards were only one parameter that limited agricultural use of sewage sludge stabilized chemically and biologically under anaerobic conditions. 


\section{CONCLUSIONS}

- Physical and chemical properties of municipal sewage sludge were dependent on the method of purification and methods of their processing and load of sewage treatment plant.

- These sewage sludges contain a significant amount of organic matter and nutrients but heavy metals did not exceed acceptable standards for municipal sewage sludge used in agriculture.

- From the analysis of reports on waste generation in the years 2007-2012 in the Mazovia voivodship resulted that assessed municipal sludge treated biologically derived from small sewage treatment plants do not endanger bacteriological. Sewage sludge treated by other methods from wastewater treatment plants serving more than 50 thousand of equivalent number of residents did not meet sanitary standards.

\section{REFERENCES}

1. Bagge E., Sahlström L., Albihn A. 2005. The effect of hygienic on the microbial flora of bio waste at biogas plants. Water Research 39, 4879-4886.

2. Czechowska-Kosacka A. 2007. Influence of sewage sludge solidification on immobilisation of heavy metals. Polish J. Environ. Stud. 16, (2A), 625-628.

3. Gochefeld M. 2003. Cases of mercury exposure, bioavailability, and absorbtion. Ecotoxicology and Environmental Safety 56, 174.

4. http://wios.warszawa.pl

5. Jakubus M. 2005. Sewage sludge characteristics with regard to their agricultural and reclamation usefulness, Fol. Univ. Agric. Stetin. 244, Agricultura $99,73-82$.

6. Jakubus M. 2006. Wpływ wieloletniego stosowania osadu ściekowego na zmiany wybranych właściwości chemicznych gleby. Zesz. Probl. Post. Nauk Rol. 512, 209-219.

7. Leszczyński S., Brzychczyk B. 2007. Thermal utilization of sewage sludge and municipal organic waste towards hydrogen production. Pol. J. Environ. Studies 16, 3B, 290-294.

8. Maćkowiak Cz. 2000. Skład chemiczny osadów ściekowych i odpadów przemysłu spożywczego o znaczeniu nawozowym. Nawozy i Nawożenie R II, 3(4) 3a, 131-149.

9. Malinowska E., Kalembasa D. 2013. Contents of some selected elements in Miscanthus sacchariflorus (Maxim.) Hack biomass under the influence of sewage sludge fertilization in cultivation experiment. Ecol. Chem. Eng. A 20(2), 203-211.

10. Mazur T. 2000. Rolnicza utylizacja stałych od- padów organicznych. Zesz. Probl. Post. Nauk Rol. 472, 507-516.

11. Pawłowski L., Kotowski M., Kotowska U., Czechowska A. 2000. Utylization of sewage sludge in cement kilns. Kluwer Academic/Pulisher, Environ. Sci. Research, 58, 41-54, New York.

12. Raport dotyczący wytwarzania odpadów $\mathrm{z}$ lat 2007-2012 w województwie mazowieckim [online: dostęp dn. 4.11.2014, http://www.mazowia.pl]

13. Rosik-Dulewska Cz. 2000. Podstawy gospodarki odpadami. PWN, Warszawa, ss. 305.

14. Rosik-Dulewska Cz. 2001. Zawartość składników nawozowych oraz metali ciężkich i ich frakcji w kompostach z odpadów komunalnych. Zesz. Probl. Post. Nauk Rol. 477, 467-477.

15. Rozporządzenie Ministra Ochrony Środowiska w sprawie komunalnych osadów ściekowych z dnia 13.07.2010 r.(Dz.U. Nr 137, poz. 924).

16. Rozporządzenie Ministra Ochrony Środowiska w sprawie standardów jakości gleby oraz standardów jakości ziemi z dnia 9.09.2002 r. (Dz.U. Nr 165, poz. 1359).

17. Sahlström L., Aspan A., Bagge E., DanielssonTham M.L., Albihn A. 2004. Bacterial pathogen incidences in sludge from swedish sewage treatment plant. Wat. Res. 38, 1989-1994.

18. Simonetti M., Rossi G., Cabbai V., Goi D. 2014. Tests on the effect of ultrasonic treatment on two different activated sludge waste. Environ. Prot. Eng. 40 (1), 23-34.

19. Skorbiłowicz M. 2002. Charakterystyka osadów ściekowych z wybranych oczyszczalni z województwa podlaskiego pod względem zawartości metali ciężkich. Acta Agroph. 73, 277-283.

20. Speir T.W., Schaik A.P. Van, Percival H.J., Close M.E., Pang L.P. 2003. Heavy metals in soil, plants and grundwater following high-rate sewage sludge application to land. Water, Air and Soil Pollution 150 (1-4), 319-358.

21. Stypka T., Flaga-Maryańczyk A. 2013. Comparative analysis of municipal solid waste systems: Cracow case study. Environ. Prot. Eng. 39 (4), 135-153.

22. Ustawa o odpadach z dnia 14 grudnia 2012 roku, rozdz. 4. Komunalne osady ściekowe, art. 96.

23. Walczak M., Lalke-Porczyk E. 2009. Occurrence of bacteria Salmonella sp. in sewage sludge used in agriculture. Environ. Prot. Eng. 35 (4), 5-12.

24. Wang Q., Kim D., Dionysion D.D., Sorial G.A., Timberlake D. 2004. Sources and remediation for mercury contamination in aquatic systems - a literature review, J. Environ. Pollut. 131, 323.

25. Wardas M., Pawlikowski M., Gurda M., Idzik M., Jagła A., Janas J., Morusek J. 2002. Cynk w osadach gospodarki wodno-ściekowej miasta Krakowa. [W:] Cynk w środowisku - problemy ekologiczne i metodyczne. Zesz. Nauk. Komit. „Człowiek i Środowisko", PAN, Warszawa 33, 253-262. 